The University of Southern Mississippi

The Aquila Digital Community

Faculty Publications

$8-1-2000$

\title{
The Influence of the Pressure Head on the Indonesian Seas Circulation
}

William H. Burnett

Stennis Space Center

Vladimir M. Kamenkovich

University of Southern Mississippi, vladimir.kamenkovich@usm.edu

George L. Mellor

Princeton University

Arnold L. Gordon

Lamont-Doherty Earth Observatory of Columbia University

Follow this and additional works at: https://aquila.usm.edu/fac_pubs

Part of the Marine Biology Commons

\section{Recommended Citation}

Burnett, W. H., Kamenkovich, V. M., Mellor, G. L., Gordon, A. L. (2000). The Influence of the Pressure Head on the Indonesian Seas Circulation. Geophysical Research Letters, 27(15), 2273-2276.

Available at: https://aquila.usm.edu/fac_pubs/4151

This Article is brought to you for free and open access by The Aquila Digital Community. It has been accepted for inclusion in Faculty Publications by an authorized administrator of The Aquila Digital Community. For more information, please contact Joshua.Cromwell@usm.edu. 


\title{
The influence of the pressure head on the Indonesian Seas circulation
}

\author{
William H. Burnett \\ Naval Meteorology and Oceanography Command, Stennis Space Center, MS \\ Vladimir M. Kamenkovich \\ Department of Marine Science, The University of Southern Mississippi, Stennis Space Center, MS
}

George L. Mellor

Program in Atmospheric and Oceanic Sciences, Princeton University, Princeton, NJ

Arnold L. Gordon

Lamont-Doherty Earth Observatory of Columbia University, Palisades, NY

\begin{abstract}
A high resolution, regional, non-linear, barotropic ocean model (2D POM) was used to show that a pressure difference between the Pacific and Indian Ocean does not significantly influence the total transport of the Indonesian throughflow.
\end{abstract}

There is a persistent pressure difference between the $\mathrm{Pa}$ cific and Indian Ocean. Based on a channel flow analogy, Wyrtki [1961, 1987] suggested that this pressure difference is a dominant factor determining the total transport of the Indonesian throughflow. This conclusion was founded on the assumption that, for the channel's overall momentum balance, the pressure head is essentially balanced by the frictional forces. This is true if the bottom topography is not taken into account. In the presence of bottom topography the resultant horizontal component of the pressure forces acting on the bottom (the bottom form stress) becomes an important factor. In principle, the bottom form stress can essentially balance the corresponding pressure head which is why the pressure head may not strongly control the total transport of the channel flow. Taking the Indonesian Seas' complicated bottom topography into consideration, we hypothesize that the Pacific-Indian Ocean pressure difference may not significantly influence the total transport of the Indonesian throughflow. The purpose of this note is to test the hypothesis using a high-resolution barotropic ocean model centered over the Indonesian Seas area. In such a model we will essentially specify the total transport of the throughflow, $Q$. We will show, however, that there might exist many steady-state regimes having practically the same $Q$, but substantially different inter-ocean pressure differences, $\triangle P$, implying a rather weak relation between $Q$ and $\triangle P$ [Burnett and Kamenkovich 1998; 1999]. A regional model cannot reveal the dominant factors determining $Q$ but it can provide the estimate of the sensitivity of $Q$ to $\triangle P$.

We will use the barotropic version of the Princeton Ocean Model (2D version of POM) from Blumberg and Mellor [1987]. Figure 1 shows the model domain for the area from

Copyright 2000 by the American Geophysical Union.

Paper number 1999GL010918.

0094-8276/00/1999GL010918\$05.00 $20^{\circ} \mathrm{S}$ to $11^{\circ} \mathrm{N}$ and $111^{\circ} \mathrm{E}$ to $142^{\circ} \mathrm{E}$. The domain is covered by $250 \times 250$ grid cells at approximately $10 \mathrm{~km}$ resolution. The domain includes land grid points (islands, continents, etc.). The time step is equal to 14 seconds.

Three open ports are considered to simulate the Mindanao Current (MC) inflow, the North Equatorial Countercurrent (NECC) outflow, and the Indian Ocean (IO) outflow; see Table 1. The location of the port at the western boundary does not correspond to observed current patterns. It was an ad hoc choice to minimize the impact of the formation of a computational western boundary layer at the port, caused by a mismatch between specified velocities at the open boundary and true velocities dynamically compatible with the interior. The location of this port influences the circulation in the Indian Ocean sector of our domain but does not influence the circulation within the Indonesian Seas which is of primary interest to us. For this study, we closed a port near the equator at the eastern boundary, corresponding to the New Guinea Coastal Current, through which the South Pacific water enters the domain. Subsequent experiments will include this eastern boundary port.

The bottom topography is incorporated from the ETOPO5 bathymetric database using a resolution of $1 / 12^{\circ}$. Shallow seas that feed into the Indonesian Seas area - the northern Java Sea and the eastern Arafura Sea - are masked since they do not noticeably influence the total transport of the Indonesian throughflow.

Based on the POM equations we calculate $U$ and $V$ (the horizontal, depth-averaged velocities) and $\eta$ (the sea surface elevation) at each grid cell with subsequent masking at the land cells. The normal and tangential velocities are set to zero at the coasts and at the domain boundary outside the open ports. Two types of experiments are performed. In the experiment of type 1, the normal and tangential velocities at the ports are prescribed. The total transports through these ports are taken from model analyses and historical observations [e.g. Miyama et al. 1995; Godfrey 1996; Lukas et al. 1996; Gordon and McClean 1999] with the total inflow and outflow balanced to ensure mass conservation. For this study, transports were selected to model a boreal winter throughflow of $5 \mathrm{~Sv}$ based on the latest results by Gordon and $M c$ Clean [1999]. The distribution of the normal velocities across the ports is modeled by simple functions and 
Table 1. Prescribed transports through the three open ports. Ports Transports, Sv

\begin{tabular}{lr}
\hline North (MC inflow) & 27.5 \\
West (IO outflow) & 5.0 \\
East (NECC outflow) & 22.5 \\
\hline
\end{tabular}

tangential velocities at the ports are set to zero. The model was run for a year, sufficient to reach a steady state.

In the experiment of type 2 sea-surface elevations and tangential velocities at the ports are prescribed. In experiments of type 2 some relaxation is applied within the outflow ports to suppress numerical noise [Martinsen and Engedahl 1987]. The results of both types of experiments did not noticeably depend on the variation of prescribed tangential velocities at the ports.

Direct wind forcing is not considered in these experiments. It is clear, however, that the specified transports through the ports or the sea-surface elevations at the ports are ultimately set up by the wind (both outside and inside the region).

Figure 1 shows a horizontal velocity pattern for Experiment 1, typical for all subsequent experiments and compatible with the Gordon and Fine [1996] schematic for the Indonesian Seas. The open port Mindanao Current (inflow) branches and flows toward the North Equatorial Countercurrent (open port), the Makassar Strait, and the Malucca Sea. The Makassar Strait transport splits between the Lombok Strait and the Flores Sea, recombining with the Malucca Sea flow. Once this combined Flores/Malucca flow has reached the Banda Sea, it recurves through the Timor passages (Ombai Strait to the north and Timor Passage to the south). In the Indian Ocean all branches of the Indonesian throughflow merge and leave the area via the Indian Ocean open port, as is prescribed by the configuration of the model.

To check our main hypothesis we performed a series of experiments of type 2 with various relaxation parameters. To specify the sea-surface elevation at the ports we took the output of Experiment 1 and increased (decreased) it by a constant value of $2.5 \mathrm{~mm}$ at the north and east ports and decreased (increased) it by a constant value of $4.5 \mathrm{~mm}$ at the western port. Based on geostrophy, we should not expect any substantial changes in the normal velocities at the mouth of the ports in the corresponding runs. [Note that we are considering the external barotropic mode. We expect that for a relevant baroclinic experiment, the corresponding values of $\eta$ will be an order of magnitude higher.] The initial sea-surface elevation is not changed but the sea-surface elevation's boundary conditions are linearly ramped from zero to the final value during approximately one month period.

Results from Experiment 2 produced qualitatively the same horizontal velocity pattern as Figure 1 . The interocean sea-surface elevation difference, $\Delta \eta$, is calculated by subtracting the sea surface elevation at the specified point in the western port's mouth from the sea surface elevation at the specified point in the northern port's mouth. For Experiment $1, \triangle \eta=11.1 \mathrm{~mm}$; for Experiment 2A ( $\eta$-increase of $2.5 \mathrm{~mm}$ at the north and east ports), $\Delta \eta=15.9 \mathrm{~mm}$; and for Experiment 2B ( $\eta$-decrease of $2.5 \mathrm{~mm}$ at the north and
Table 2. Total transports (Sv) through three open ports and seven passages for Experiment 1 (prescribed normal velocities) and Experiment 2 (perturbed sea surface elevations of $+2.5 \mathrm{~mm}$ (A) and $-2.5 \mathrm{~mm}$ (B)). Positive transport values denote either eastward or northward flow.

\begin{tabular}{lrrr} 
Passage & Exp 1 & Exp 2A & Exp 2B \\
\hline West port & -5.00 & -7.52 & -2.49 \\
East port & -22.50 & -20.89 & -23.65 \\
North port & +27.50 & +28.41 & +26.15 \\
Lombok & -1.14 & -1.74 & -0.57 \\
Makassar & -1.91 & -2.75 & -1.06 \\
Flores & +0.48 & +0.60 & +0.36 \\
Ombai & -2.15 & -3.29 & -1.06 \\
Timor & -1.40 & -2.06 & -0.71 \\
Malucca & -3.59 & -5.13 & -2.06 \\
Halmahera & $+\mathbf{0 . 2 6}$ & $+\mathbf{0 . 0 4}$ & +0.48 \\
\hline
\end{tabular}

east ports), $\Delta \eta=6.0 \mathrm{~mm}$. The numerical values of \pm 2.5 $\mathrm{mm}$ are considered as parameters for these experiments.

Table 2 provides the transport values for the three open ports and seven Indonesian Seas passages. Changing $\Delta \eta$ more than two times in Experiment 2 caused from $3 \%$ to $7 \%$ variations in the northern and eastern ports' transports, $Q_{N}$ and $Q_{E}$ respectively. We can conclude that $Q_{N}$ and $Q_{E}$ are practically not affected by substantial changes in $\triangle \eta$. We see, however, that some discrepancies are inevitable since we cannot expect total geostrophy at the mouth of these ports. The western port's transport, $\left|Q_{W}\right|$, is the difference between $\left|Q_{N}\right|$ and $\left|Q_{E}\right|$. Since $\left|Q_{W}\right| \ll\left|Q_{N}\right|$ and $\left|Q_{W}\right| \ll\left|Q_{E}\right|,\left|Q_{W}\right|$ is not an adequate measure of the influence of $\Delta \eta$. Thus, Table 2 shows that the change in $\Delta \eta$ did not practically influence the northern and eastern ports'

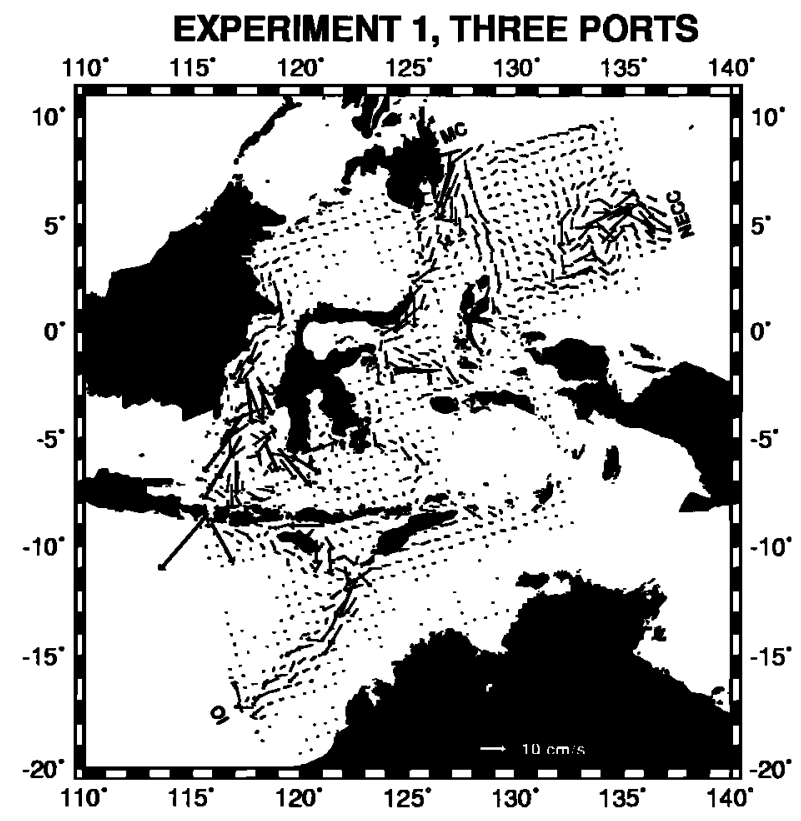

Figure 1. Model domain centered over the Indonesian Seas area with horizontal velocities from Experiment 1. Coordinates of the domain corners: South-West $\left(20^{\circ} \mathrm{S} ; 118^{\circ} \mathrm{E}\right)$; North-West $\left(4^{\circ} \mathrm{N} ; 111^{\circ} \mathrm{E}\right)$; North-East $\left(11^{\circ} \mathrm{N} ; 135^{\circ} \mathrm{E}\right)$; SouthEast $\left(13^{\circ} S ; 142^{\circ} \mathrm{E}\right)$. Port locations for the Mindanao Current (MC), North Equatorial Countercurrent (NECC), and Indian Ocean (IO) are labeled. Land is shown in black. 

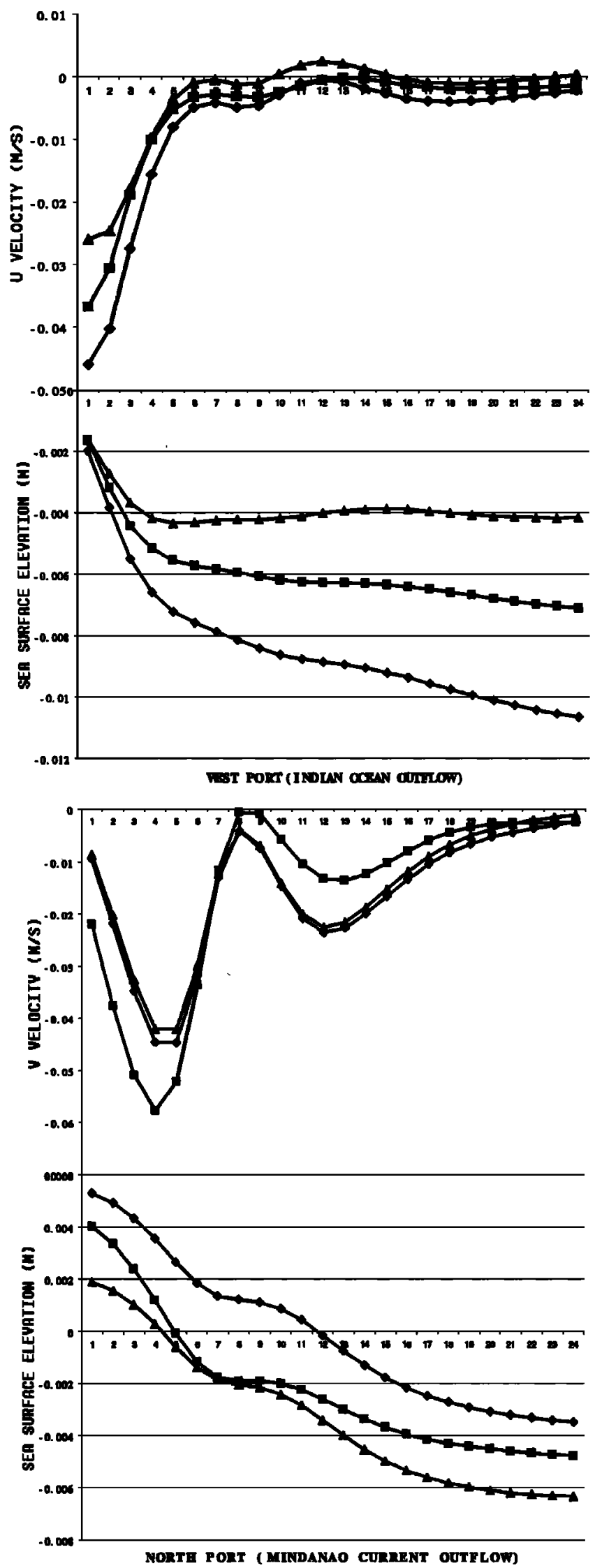

Figure 2. Depth-averaged horizontal velocities $(\mathrm{m} / \mathrm{s})$ and sea surface elevations $(\mathrm{m})$ at the mouths of the west (Indian Ocean outflow) and north (Mindanao Current inflow) ports from Experiment 1 (squares) and 2 (2A - diamonds; 2B - triangles). The port's grid numbers are labeled along the horizontal axes. See further explanations in the text. 
transports but it did affect the transports through the straits by altering the amount, but not the direction, of the flow.

Figure 2 shows the normal velocities and sea surface elevations at the mouths of the north and west open ports for Experiments 1 and 2. The change in $\Delta \eta$ does not affect the northern and western open port's normal velocities noticeably. Overall, the graphs (not all given here) show that variations in $\Delta \eta$ do not substantially affect the open port's normal velocities.

The detailed momentum budget will be given elsewhere [Burnett et al. 2000]. Here we stress only that the increase (decrease) in the pressure difference between the Pacific and Indian Ocean ports is essentially balanced by the pressure forces acting on the bottom (the bottom form stress). Thus, the bottom relief appears to be a very important factor.

Based on numerous experiments, only the most typical are described here, we conclude that the inter-ocean seasurface elevation difference, $\Delta \eta$, does not significantly influence the total transport of the Indonesian throughflow, $Q$. Yet, the inter-ocean sea-surface elevation difference did affect the transport through individual straits and passages within the Indonesian Seas area.

Acknowledgments. The authors gratefully acknowledge discussions with D. Nechaev, G. Peggion, I. Shulman, and an anonymous reviewer. We are also grateful to $\mathrm{D}$. Jaffe for his contributions to the project. W. Burnett was supported by U.S. Navy funds. V. Kamenkovich, G. Mellor, A. Gordon, were supported by NSF grant OCE 96-33470. The model analysis was supported by the Department of Defense's Major Shared Resource Center Cray C90 supercomputer.

\section{References}

Burnett, W. H., and V. M. Kamenkovich, On the influence of the pressure head on the Indonesian Seas circulation, Supplement to EOS, AGU, Volume 79, No. 45, p. F408, Abstracts of AGU 1998 Fall Meeting, 1998.

Burnett, W. H., and V. M. Kamenkovich, The influence of the pressure head on the Indonesian Seas circulation. Third Conference on Coastal Atmospheric and Oceanic Prediction and Processes; 3-5 November 1999; New Orleans, LA. American Meteorological Society, 385-388, 1999.
Burnett, W. H., V. M. Kamenkovich, D. Jaffe, A. L. Gordon, and G. L. Mellor, Dynamical balance in the Indonesian Seas circulation. Geophys. Res. Letters (In Press), 2000.

Blumberg, A. F., and G. L. Mellor, A description of a threedimensional coastal ocean circulation model, Coastal and Estuarine Sciences 4, Three-Dimensional Coastal Ocean Models, Amer. Geophys. Union, Washington D.C., 1-16, 1987.

Godfrey, J. S., The effect of the Indonesian throughflow on ocean circulation and heat exchange with the atmosphere: A review, J. Geophys. Res., 101, 12,217-12,237, 1996.

Gordon, A. L., and R. Fine, Pathways of water between the Pacific and Indian Oceans in the Indonesian Seas, Nature, 379 (6561), 146-149, 1996.

Gordon, A. L., and J. L. McClean, Thermohaline stratification of the Indonesian Seas: model and observations, J. Phys. Oceanogr., 29, 198-216, 1999.

Lukas, R., T. Yamagata, and J. P. McCreary, Pacific low-latitude western boundary currents and the Indonesian throughflow, $J$. Geophys. Res., 101, 12,209-12,216, 1996.

Martinsen, E. A, and H. Engedahl, Implementation and testing of a lateral boundary scheme as an open boundary condition in a barotropic ocean model, Coastal Engineering, 11, 603-627, 1987.

Miyama, T., T. Awaji, K. Akitomo, and N. Imasato, Study of seasonal transport variations in the Indonesian Seas, J. Geophys. Res., 100, 20,517-20,541, 1995.

Wyrtki, K., Physical oceanography of the Southeast Asian waters, NAGA Rep. 2, 195 pp., Scripps Inst. of Oceanogr., La Jolla, Calif., 1961.

Wyrtki, K., Indonesian throughflow and the associated pressure gradient, J. Geophys. Res., 92, 12,941-12,946, 1987.

W. H. Burnett, Naval Meteorology and Oceanography Command, Stennis Space Center, MS 39529; e-mail: BurnettB@cnmoc.navy.mil

A.L. Gordon, Lamont-Doherty Earth Observatory of Columbia University, Palisades, NY 10964.

V. M. Kamenkovich, Department of Marine Science, The University of Southern Mississippi, Bldg 1103, Stennis Space Center, MS 39529

G. L. Mellor, Program in Atmospheric and Oceanic Sciences, Sayre Hall, Forrestal Campus, Princeton University, Princeton, NJ 08544

(Received July 2, 1999; revised March 9, 2000; accepted May 10, 2000.) 